DOI: https://doi.org/10.31933/jimt.v2i2 Received: 29 Oktober 2020, Revised: 25 November 2020, Publish: 5 Desember 2020

\begin{tabular}{|c|c|}
\hline DINASTI & $\begin{array}{l}\text { JMT } \\
\text { JURNAL ILMU MANAJEMEN } \\
\text { TERAPAN }\end{array}$ \\
\hline
\end{tabular}

\title{
PENGARUH GAYA KEPEMIMPINAN, KEPUASAN KERJA, DAN MOTIVASI KERJA TERHADAP KINERJA ACCOUNT REPRESENTATIVE DI LINGKUNGAN KANTOR WILAYAH DJP SUMATERA UTARA II (SEBUAH LITERATUR REVIEW MANAJEMEN SUMBER DAYA MANUSIA)
}

\section{Jogi Soaduon Lumbantobing}

Program Studi Magister Manajemen Universitas Terbuka, Indonesia, jogimavro@ gmail.com

\section{Corresponding Author: First Author}

\begin{abstract}
Abstrak: Sumber daya manusia merupakan salah satu unsur yang sangat penting bagi organisasi pemerintah. Untuk mencapai keberhasilan tujuan organisasi maupu individu diperlukan tatanan secara sistematis dan terstruktur yang diatur dalam sebuah pola manajemen organisasi. Artikel ini mereview untuk mengetahui bagaimana hubungan dan sejauh mana pengaruh gaya kepemimpinan, kepuasan kerja karyawan dan motivasi bekerja terhadap kinerja Account Representative di lingkungan kantor wilayah DJP Sumatera Utara II, yang merupakan suatu studi literatur dari berbagai penelitian sebelumnya yang dianggap relevan, agar dapat dijadikan bahan referensi bagi peneltian selanjutnya dibidang sumber daya manusia dalam menentukan strategi dan kebijakan sebuah organisasi.
\end{abstract}

Kata Kunci:, Motivasi Kerja, Gaya Kepemimpinan, Kepuasan Kerja, Kinerja Pegawai

\section{PENDAHULUAN \\ Latar Belakang Masalah}

Direktorat Jenderal Pajak (Dirjen Pajak atau DJP) adalah salah satu direktorat jenderal di bawah Kementerian Keuangan Indonesia yang memiliki tugas merumuskan serta melaksanakan kebijakan dan standardisasi teknis di bidang perpajakan. Sebagai organisasi, tentu kesuksesan DJP juga tidak terlepas salah satunya dari keberhasilan DJP dalam mengelola para pegawai sebagai Sumber Daya Manusia yang dimilikinya. Dengan jumlah pegawai DJP yang cukup besar, sebanyak 45.714 pegawai (data http://www.sdm.kemenkeu.go.id/ per 20 Oktober 2020), pengelolaan kinerja pegawai dan pencapaian tujuan organisasi tentu tidak hanya berpusat di tingkat pusat (Kantor Pusat), namun juga menjadi perhatian pada unit organisasi yang lebih kecil Kantor Wilayah dan seperti Kantor Pelayanan Pajak (KPP).

Kantor Wilayah DJP Sumatera Utara II adalah Kanwil Ditjen Pajak yang membawahi Kantor Pelayanan Pajak (KPP) di lingkungan wilayah Sumatera Utara II antara lain Pematang Siantar, Tebing Tinggi, Kisaran, Rantau Prapat, Kabanjahe, Balige, Sibolga dan Padang 
Sidempuan. Di tiga tahun terakhir ini (2016-2018) kinerja beberapa KPP Pratama di lingkungan Kanwil DJP Sumatera Utara II tidak tercapai khususnya atas kinerja penerimaan pajak. Meski banyak sekali faktor yang dapat mempengaruhi tercapainya target penerimaan pajak tersebut, seperti besaran target penerimaan pajak itu sendiri, kondisi perekonomian dan pertumbuhan ekonomi nasional, tingkat kepatuhan dan kesadaran WP serta faktor-faktor lainnya, kinerja petugas pajak khususnya Account Representative bagian pengawasan pajak tentu juga berpengaruh terhadap kinerja kantor pajak itu sendiri.

Kantor Pelayanan Pajak (KPP) merupakan unit organisasi DJP yang langsung berhubungan dengan wajib pajak, dan salah satu jabatan yang langsung berhubungan dengan tugas tersebut adalah Account Representative (AR). Account Representative merupakan salah satu ujung tombak penggalian potensi penerimaan Negara di bidang perpajakan yang mengemban tugas intensifikasi perpajakan melalui pemberian bimbingan/himbauan, konsultasi, analisis dan pengawasan terhadap Wajib Pajak. Sebagai salah satu bagian yang langsung menangani dan bersentuhan langsung dengan WP (konsultasi dan pengawasan), kinerja AR yang baik dan maksimal tentu berpengaruh dalam pencapaian sasaran/tujuan organisasi. Sudah sepatutnya, Kantor Pelayanan Pajak harus mampu memaksimalkan kinerja para AR nya. Namun sejauh ini perhatian terhadap kinerja petugas pajak khususnya AR dan bagaimana meningkatkannya belum mendapat perhatian utama dari organisasi dan para pimpinan di organisasi.

Dalam artikel ini penulis ingin membahas faktor-faktor yang mempengaruhi kinerja Account Representative (studi literatur sumber daya manusia) yaitu : pengaruh Gaya Kepempinan (X1), Kepuasan Kerja (X2) dan Motivasi Kerja (X3) terhadap Kinerja Account Representative (Y1).

\section{Rumusan Masalah.}

Berdasarkan latar belakang akan di rumuskan masalah yang akan di bahas pada artikel literature review agar lebih focus pada kajian pustaka dan hasil serta pembahasan nanti, yaitu:

1. Apakah Gaya Kepemimpinan memiliki hubungan dan berpengaruh terhadap Kinerja Account Representative.

2. Apakah Kepuasan Kerja memiliki hubungan dan berpengaruh terhadap terhadap Kinerja Account Representative.

3. Apakah Motivasi Kerja memiliki hubungan dan berpengaruh terhadap Kinerja Account Representative.

\section{KAJIAN PUSTAKA}

\section{Kepemimpinan dan Gaya Kepemimpinan}

Menurut Terry G. R dalam Kartono (2008) kepemimpinan adalah aktivitas untuk mempengaruhi orang-orang supaya diarahkan mencapai tujuan organisasi. Menurut Benis dalam Kartono (2008) kepemimpinan adalah "The process by which an agent induces a subordinate to behave an a desires manner" maksudnya suatuproses dimana seorang agen menyebabkan bawahan bertingkah laku menurut suatu cara tertentu. Menurut Biatna (2008) kepemimpinan secara luas meliputi proses mempengaruhi dalam menentukan tujuan organisasi, memotivasi perilaku pengikut untuk mencapai tujuan, mempengaruhi untuk memperbaiki kelompok dan budayanya.

Menurut (Kartono, 2006), gaya kepemimpinan seseorang dapat dilihat dan dinilai dari beberapa indikator sebagai berikut: 1.Kemampuan Mengambil Keputusan. 2. Kemampuan Memotivasi. 3.Kemampuan Komunikasi. 4.Kemampuan Mengendalikan Bawahan. 5.Tanggung Jawab. 6.Kemampuan Mengendalikan Emosional.

Gaya kepemimpinan adalah perilaku dan strategi, sebagai hasil kombinasi dari falsafat, keterampilan, sifat, sikap, yang sering diterapkan seorang pemimpin ketika ia mencoba 
mempengaruhi kinerja bawahannya. Dalam gaya kepemimpinan memiliki tiga pola dasar yaitu yang mementingkan pelaksanaan tugas, yang mementingkan hubungan kerja sama, dan yang mementingkan hasil yang dapat dicapai. Sehingga gaya kepemimpinan yang paling tepat adalah suatu gaya yang dapat memaksimumkan produktivitas, kepuasan kerja, penumbuhan, dan mudah menyesuaikan dengan segala situasi (Biatna, 2008).

Menurut Northouse (2017) gaya kepemimpinan mengandung pola perilaku dari seseorang yang mencoba untuk memengaruhi orang lain. Hal itu mencakup perilaku perintah (tugas) dan perilaku pemberi dukungan (hubungan). Perilaku perintah membantu anggota kelompok mencapai tujuan dengan memberi perintah, mencapai tujuan dan metode evaluasi, menetapkan tenggat waktu, menetapkan peran, dan menunjukan cara mencapai tujuan. Perilaku perintah menjelaskan, sering kali dengan komunikasi satu arah, apa yang perlu dilakukam, bagaimana hal itu dilaksanakan, dan siapa yang bertanggung jawab melakukan itu. Perilaku pemberi dukungan membantu anggota kelompok merasa nyaman tentang diri mereka, rekan kerja mereka, serta situasi. Perilaku pendukung melibatkan komunikasi dua arah dan merespons yang menunjukan dukungan sosial serta emosional kepada orang lain.

Gibson (1996) seperti yang dikutip Trisnaningsih (2007) telah dilakukan penelitian gaya kepemimpinan tentang perilaku pemimpin melalui dua deminsi, yaitu: consideration dan initiaying structure. Consideration (konsiderasi) adalah gaya kepemimpinan yang menggambarkan kedekatan hubungan antara bawahan dengan atasan, adanya saling percaya, kekeluargaan, menghargai gagasan bawahan, dan adanya komunikasi antara pimpinan dengan bawahan. Pemimpin yang memiliki konsiderasi yang tinggi menekankan pentingnya komunikasi yang terbuka dan parsial. initiaying structure (struktur inisiatif) merupakan gaya kepemimpinan yang menunjukkan bahwa pemimpin mengorganisasikan dan mendefinisikan hubungan dalam kelompok, cenderung membangun pola dan saluran komunikasi yang jelas, serta menjelaskan cara mengerjakan tugas yang besar.

Trisnaningsih (2007) mengatakan bahwa gaya kepemimpinan seseorang manajer akan berpengaruh langsung terhadap efektivitas kelompok kerja. Kelompok kerja dalam perusahaan merupakan pengelompokan kerja dalam bentuk unit kerja dan masing-masing unit kerja itu dipimpin oleh seorang manajer. Gaya manajer untuk mengelola sumber daya manusia dalam suatu unit kerjaakan berpengaruh pada peningkatan kinerja unit, yang pada akhirnya akan mempengaruhi kinerja perusahaan secara keseluruhan.

Menurut Davis (2010), ciri-ciri utama yang harus dimiliki oleh seorang pemimpin adalah:

1) Kecerdasan (Intelligence): Penelitian-penelitian pada umumnya menunjukkan bahwa seorang pemimpin yang mempunyai tingkat kecerdasan yang lebih tinggi dari pada pengikutnya, tetapi tidak sangat beberbeda.

2) Kedewasaan, Sosial dan Hubungan Sosial yang luas (Social maturity and Breadht): Pemimpin cenderung mempunyai emosi yang stabil dan dewasa atau matang, serta mempunyai kegiatan dan perhatian yang luas.

3) Motivasi diri dan dorongan berprestasi: Pemimpin secara relatif mempunyai motivasi dan dorongan berprestasi tinggi, bekerja keras lebih untuk nilai intrinsik.

4) Sikap-sikap hubungan manusiawi: Seorang pemimpin yang sukses akan mengakui harga diri dan martabat pengikut-pengikutnya, mempunyai perhatian yang tinggi dan berorientasi pada bawahannya.

Sedangkan menurut Pasolong (2013) gaya kepemimpinan dapat diukur melalui:

1) Keputusan dibuat bersama

Pemimpin yang demokratis tidak sungkan untuk terlibat bersama-sama dengan bawahan untuk membuat keputusan serta melakukan aktivitas kerja demi pencapaian tujuan organisasi. 
2) Menghargai potensi setiap bawahannya

Kepemimpinan demokratis menghargai setiap potensi individu dan bersedia mengakui keahlian para spesialis dengan bidangnya masing-masing, mampu memanfaatkan kapasitas setiap anggota seefektif mungkin pada saat dan kondisi yang tepat.

3) Mendengar kritik, saran/pendapat dari bawahan

Mendapat kritikan, saran/pendapat dari bawahan merupakan hal yang wajar dalam kehidupan organisasi. Dengan demikian akan ada kecenderungan untuk lebih meningkatkan potensi diri dan bisa menjadi lebih baik dari sebelumnya serta belajar dari kesalahan yang telah dilakukan.

4) Melakukan kerjasama dengan bawahannya.

Pemimpin yang baik adalah pemimpin yang mampu bekerja sama/ terlibat langsung secara bersama-sama dalam menjalankan tugas demi pencapaian tujuan organisasi. Pemimpin juga tidak sungkan untuk terjun langsung kelapangan untuk menjalankan tugas.

Gaya Kepemimpinan telah banyak diteliti oleh peneliti sebelumnya diantaranya adalah : (Astria Khairiziah, et al.,2015) (Pinatih \& Gorda, 2017) (Rahadian \& Suwandana, 2017) (Riyanto, Pratomo, et al., 2017)

\section{Kepuasan Kerja}

Istilah kepuasan kerja (Job Statisfaction) merujuk pada sikap umum seorang individu terhadap pekerjaannya. Seorang dengan tingkat kepuasan kerja tinggi menunjukkan sikap yang positif terhadap kerja itu seseorang yang tidak puas dengan pekerjaannya menunjukkan sikap yang negatif terhadap pekerjaan tersebut (Robbins, 2003).

Kepuasan kerja adalah seperangkat perasaan pegawai tentang menyenangkan atau tidak pekerjaan mereka (Davis dan Newstron, 1989 dalam Rahmawati dan Widagdo, 2001). Kepuasan kerja merupakan perasaan senang atau tidaknya seseorang yang relatif terhadap pekerjaannya yang berbeda dari pemikiran objektif dan keinginan perilaku. Masih menurut Davis dan Newstron, apabila pegawai bergabung dalam suatu organisasi, ia membawa serta seperangkat keinginan, kebutuhan, hasrat dan pengalaman masa lalu yang menyatu membentuk harapan kerja. Dengan demikian sumber kepuasan kerja adalah adanya kesesuaian antara harapan seseorang yang timbul dan imbalan yang disediakan pekerjaan, jadi kepuasan kerja juga berkaitan erat dengan teori keadilan, perjanjian psikologis dan motivasi

Menurut Spector (1997) faktor-faktor penyebab kepuasan kerja dapat diklasifikasikan ke dalam dua kategori umum, yaitu faktor-faktor lingkungan pekerjaan dan faktor-faktor individu. Enam faktor penyebab kepuasan kerja yang termasuk ke dalam faktor lingkungan pekerjaan antara lain: karakteristik pekerjaan, batasan dari organisasi (organizational constraints), peran dalam pekerjaan, konflik antara pekerjaan dan keluarga, gaji, dan stres kerja. Sedangkan dua faktor penyebab kepuasan kerja yang termasuk ke dalam faktor individu (Spector, 1997) antara lain: karakteristik kepribadian, dan kesesuaian antara individu dengan pekerjaan.

Pengukuran kepuasan kerja individu dengan menggunakan Job Satisfaction Survey (Spector, 1997) mengandung pengukuran Sembilan aspek sebagai berikut:

a. Pay (gaji): kepuasan individu terhadap gaji dan kenaikan gaji.

b. Promotion (promosi): kepuasan individu terhadap kesempatan promosi.

c. Supervision (atasan): kepuasan individu terhadap atasan.

d. Fringe benefits (tunjangan): kepuasan individu terhadap tunjangan yang diberikan perusahaan.

e. Contingent rewards (imbalan non-finansial): kepuasan individu terhadap imbalan nonfinansial yang diberikan karena performa baik yang ditunjukkan oleh individu dalam bekerja 
f. Operating conditions (kondisi operasional): kepuasan individu terhadap peraturanperaturan dan prosedur-prosedur yang berlaku dalam organisasi

g. Co-workers (rekan kerja): kepuasan individu terhadap rekan-rekan kerja.

h. Nature of work (tipe/jenis pekerjaan): kepuasan individu terhadap tipe pekerjaan yang dilakukan.

i. Communication (komunikasi): kepuasan individu terhaddap komunikasi yang terjalin dalam organisasi

Menurut Hasibuan (2006), indikator kepuasan kerja adalah (1) kondisi kerja, (2) promosi jabatan, (3) rekan kerja, (4) kedisiplinan dan (5) prestasi kerja. (Luthans, 2006) memandang dimensi kepuasan kerja meliputi (1) pekerjaan itu sendiri, (2) gaji, (3) kesempatan promosi, (4) pengawasan, dan (5) rekan kerja. Jadi menurut pendapat para ahli diatas, maka indikator kepuasan kerja yang digunakan dalam penelitian ini (1) gaji, (2) rekan kerja, (3) prestasi kerja, (4) pekerjaan itu sendiri dan (5) kesempatan promosi.

Kepuasan kerja sudah banyak diteliti oleh peneliti sebelumnya diantaranya adalah : ( Prayatna \& Subudi, 2016; Rahadian \& Suwandana, 2017; Rismayadi \& Maemunah, 2016)

\section{Motivasi Kerja}

Motivasi merupakan unsur penting dalam diri manusia, yang berperan mewujudkan keberhasilan dalam usaha atau pekerjaan manusia. Motivasi menurut Hasibuan (2002) adalah pemberian daya penggerak yang menciptakan kegairahan kerja seseorang, agar mau bekerja sama, bekerja efektif dan terintegrasi dengan segala daya upayanya untuk mencapai kepuasan.

Menurut Malthis (2006:114), motivasi adalah keinginan dalam diri seseorang yang menyebabkan orang tersebut bertindak. Biasanya orang bertindak karena suatu alasan untuk mencapai tujuan. Memahami motivasi sangatlah penting karena kinerja, reaksi terhadap kompensasi dan persoalan sumber daya manusia yang lain dipengaruhi dan mempengaruhi motivasi. Pendekatan untuk memahami motivasi berbeda-beda, karena teori yang berbeda mengembangkan pandangan dan model mereka sendiri.

Teori motivasi manusia yang dikembangkan oleh Malthis (2006) mengelompokkan kebutuhan manusia menjadi lima kategori yang naik dalam urutan tertentu. Sebelum kebutuhan lebih mendasar terpenuhi, seseorang tidak akan berusaha untuk memenuhi kebutuhan yang lebih tinggi. Hierarki Maslow yang terkenal terdiri atas kebutuhan fisiologis, kebutuhan akan keselamatan dan keamanan, kebutuhan akan kebersamaan, kasih sayang, dan kebutuhan akan aktualisasi diri. Kebutuhan seseorang merupakan dasar untuk model motivasi. Kebutuhan adalah kekurangan yang dirasakan oleh seseorang pada saat tertentu yang menimbulkan tegangan yang menyebabkan timbulnya keinginan.

Menurut Hafizurrahcman (2007), karakteristik pekerja yang mempunyai motivasi berprestasi tinggi, antara lain: 1) Memiliki tanggung jawab pribadi yang tinggi, 2) Memiliki Program kerja berdasarkan rencana dan tujuan nyata serta berjuang untuk merealisasikannya, 3) Memiliki kemampuan untuk mengambil keputusan dan berani mengambil risiko yang dihadapinya, 4) Melakukan pekerjaan yang berarti dan menyelesaikan dengan hasil yang memuaskan, dan 5) Mempunyai keinginan menjadi orang terkemuka yang menguasai bidang tertentu.

Untuk dapat menumbuhkan motivasi kerja yang positif di dalam diri pegawai, maka seorang pemimpin harus sungguh-sungguh memberikan perhatian pada faktor-faktor sebagai berikut (Novari, 2009): achievement (keberhasilan pelaksanaan), recognition (pengakuan), the Work it Self (pekerjaan itu sendiri), responsibilities (tanggung jawab), advancement (pengembangan).

Teori dua faktor dari Frederick Herzberg mengatakan bahwa seseorang terdorong untuk melakukan pekerjaan karena dua faktor yaitu faktor yang membuat individu merasa tidak puas 
(dissatisfiers) dan factor yang membuat individu puas (satisfiers). Menurut hasil penelitian yang dilakukan Herzberg ada dua faktor yang mendorong atau memotivasi orang untuk bekerja, yaitu:

a. Faktor Motivator

Faktor motivator disebut juga dengan kondisi intrinsik, adalah kepuasan pekerjaan yang apabila terdapat dalam pekerjaan akan menggerakkan tingkat motivasi yang kuat dalam menghasilkan kinerja karyawan. Jika kondisi ini tidak ada, maka kondisi ini ternyata tidak menimbulkan rasa ketidakpuasan yang berlebihan. Manullang (1981 : 151) menyatakan bahwa faktor-faktor motivator meliputi:

1) Achievement (keberhasilan pelaksanaan)

2) Recognition (pengakuan)

3) The work it self (pekerjaan itu sendiri)

4) Responsibilities (tanggung jawab)

5) Advancement (pengembangan)

Motivasi internal adalah motivasi yang dibangkitkan dari dirinya sendiri, dimana tenaga kerja dapat bekerja karena tertarik dan senang dengan pekerjaan yang memberikan makna, kepuasan dan kebahagiaan pada dirinya. Motivasi internal disebut juga faktor motivator.

b. Faktor Hygiene

Faktor Hygiene disebut juga dengan kondisi ekstrinsik, adalah suatu keadaan pekerja yang menyebabkan rasa tidak puas diantara para karyawan. Apabila kondisi tersebut ada, maka hal itu tidak memotivasi karyawan. Kondisi tersebut adalah faktor- faktor yang membuat individu merasa tidak puas (dissatisfiers), karena faktor- faktor tersebut diperlukan untuk mempertahankan hirarki yang paling rendah, yaitu tingkat tidak adanya kepuasan (non-dissatisfiers). Menurut M. Manullang (1981:151) menyatakan faktor hygiene meliputi:

1) Policy and administration (kebijakan dan administrasi)

2) Technical supervisior (supervisi perusahaan)

3) Interpersonal supervisor (hubungan antar pribadi)

4) Working condition (kondisi keija)

5) Wages (gaji/upah)

Faktor hygiene, pada dasarnya adalah hubungan kerja dengan lingkungan kerja dimana karyawan bekerja, sehingga apabila faktor ini diabaikan atau dibiarkan tidak sehat, maka akan menimbukan ketidak puasan para karyawan. Motivasi eksternal adalah motivasi yang berasal dari luar yang berupa peraturan dan kebijaksanaan perusahaan. Motivasi eksternal disebut faktor hygiene.

Motivasi kerja sudah banyak diteliti oleh peneliti sebelumnya diantaranya adalah : (D.I Ayu, 2013; A.H Garjito et al., 2014; Ady \& Wijono, 2013; Kiki Setiawan, 2015; Theodora Olivia,2015)

\section{Kinerja Karyawan (Account Representative)}

Berikut adalah beberapa pendapat para ahli tentang kinerja yang dikutip Sirulingga (2004), tiga diantaranya adalah:

1. Menurut Soeprihantono (2003), kinerja atau prestasi kerja adalah hasil kerja seseorang atau kelompok selama periode tertentu dibandingkan dengan berbagai kemungkinan, misalnya standar, target/sasaran atau kriteria yang telah ditentukan terlebih dahulu dan disepakati bersama. 
2. Menurut Ruky (2002), kinerja adalah sebuah penilaian sistematis atas individu karyawan mengenai prestasi kerjanya dan potensinya untuk pengembangan.

3. Menurut Suyadi (2003), kinerja atau prestasi kerja adalah hasil kerja yang dapat dicapai oleh seseorang atau sekelompok orang dalam suatu organisasi, sesuai dengan wewenang dan tanggung jawab masing- masing dalam rangka upaya mencapai tujuan organisasi bersangkutan secara legal, tidak melanggar hukum dan sesuai dengan moral dan etika.

Kinerja(performance) adalah gambaran mengenai tingkat pencapaian pelaksanaan suatu kegiatan/program/kebijakan dalam mewujudkan sasaran, tujuan, misi dan visi organisasi yang tertuang dalam strategic planning suatu organisasi. Istilah kinerja sering digunakan untuk menyebut prestasi atau tingkat keberhasilan individu maupun kelompok individu.

Menurut Sinambela (2016) kinerja pegawai adalah kemampuan pegawai dalam melakukan sesuatu keahlian tertentu. Kinerja pegawai sangatlah perlu, sebab dengan kinerja ini akan diketahui seberapa jauh kemampuan mereka dalam melaksanakan tugas yang dibebankan kepadanya. Mangkunegara (2011) kinerja merupakan hasil kerja secara kualitas dan kuantitas yang dicapai oleh seorang karyawan dalam melaksanakan tugasnya sesuai dengan tanggung jawab yang diberikan kepadanya. Wibowo (2016) kinerja adalah tentang melakukan pekerjaan dan hasil yang dicapai dari pekerjaan tersebut. Kinerja adalah tentang apa yang dikerjakan dan bagaimana cara mengerjakannya.

Secara teori banyak faktor yang dapat mempengaruhi kinerja, menurut Mangkunegara (2011) menyatakan bahwa faktor-faktor yang dapat mempengaruhi kinerja adalah:

1) Faktor kemampuan (ability. Secara psikologis, kemampuan (ability) pegawai terdiri dari kemampuan potensi (IQ) dan kemampuan reality (knowledge + skill). Artinya pegawai yang memiliki IQ di atas rata-rata (IQ 110-120) dengan pendidikan yang memadai untuk jabatannya dan terampil dalam mengerjakan pekerjaan sehari-hari, maka ia akan lebih mudah mencapai kinerja yang diharapkan. Oleh karena itu, pegawai perlu ditempatkan pada pekerjaan yang sesuai dengan keahliannya.

2) Faktor motivasi. Motivasi terbentuk dari sikap (attitude) seseorang pegawai dalam menghadapi situasi (situation) kerja. Motivasi merupakan kondisi yang menggerakkan diri pegawai yang terarah untuk mencapai tujuan organisasi (tujuan kerja). Sikap mental merupakan kondisi mental yang mendorong diri pegawai untuk berusaha mencapai prestasi kerja secara maksimal. Sikap mental pegawai harus sikap mental yang secara psikofisik (siap secara mental, fisik, tujuan,dan situasi), artinya seorang pegawai harus siap secara mental, mampu secara fisik, memahami secara fisik, memahami tujuan utama dari target kerja yang akan dicapai, mampu memanfaatkan, dan menciptakan situasi kerja.

Menurut Ruky (2002), unsur-unsur pengukuran kinerja sebagai berikut:

1. Kinerja berorientasi pada input. Cara ini merupakan cara tradisional yang menekankan pada pengukuran atau penilaian ciri-ciri kepribadian Account Representative. Ciri-ciri atau karakteristik kepribadian yang banyak dijadikan objek pengukuran adalah kejujuran, ketaatan, disiplin, loyalitas, kreativitas, adaptasi, komitmen, sopan santun dan lain-lain.

2. Kinerja yang berorientasi pada proses. Melalui cara ini, kinerja atau prestasi Account Representative yang diukur dengan cara menilai sikap dan perilaku seorang Account Representative dalam melaksanakan tugas dan tanggung jawabnya, dengan kata lain penilaian masih tetap tidak difokuskan langsung pada kuantitas dan kualitas hasil yang dicapainya, yang diteliti adalah meneliti bagaimana tugas-tugas dilakukan dan membandingkan perilaku dan sikap yang diperlihatkan dengan standar yang telah ditetapkan untuk setiap tugas yang telah dibebankan padanya.

3. Kinerja yang berorientasi pada output. Sistem ini biasa juga disebut sistem manajemen kinerja yang berbasiskan pencapaian sasaran kerja individu. Sistem ini memfokuskan 
pada hasil yang diperoleh atau dicapai oleh Account Representative. Sistem ini berbasis pada metode manajemen kinerja berbasiskan pada konsep manajemen berdasarkan sasaran.

Untuk mendapatkan informasi atas kinerja Account Representative, maka ada beberapa pihak baik itu perorangan ataupun kelompok yang biasanya melakukan penilaian atas kinerja Account Representative. Ada tiga pihak yang dapat melakukan penilaian kinerja Account Representative, yaitu:

1. Atasan langsung. Semua evaluasi kinerja pada tingkat bawah dan menengah dari organisasi dijalankan oleh atasan langsung Account Representative itu karena atasan langsung yang memberikan pekerjaan dan paling tahu kinerja Account Representativenya.

2. Rekan sekerja. Penilaian kinerja yang dilakukan oleh rekan sekerja dilaksanakan dengan pertimbangan. Pertama, rekan sekerja dekat dengan tindakan. Interaksi sehari-hari memberikan kepada Account Representative pandangan menyeluruh terhadap kinerja seseorang Account Representative dalam pekerjaan. Kedua, dengan menggunakan rekan sekerja sebagai penilaian menghasilkan sejumlah penilaian yang independen.

3. Nilai Capaian Kinerja Pegawai. Nilai Capaian Kinerja Pegawai adalah nilai capaian atas Kontrak Kinerja yang dibebankan kepada Account Representative pada awal tahun (awal periode penilaian). Adapun kontrak kinerja berisi sasaran kinerja yang menjadi target Account Representative (Indikator Kinerja Utama/IKU) untuk satu periode penilaian (biasanya satu tahun).

Kinerja karyawan sudah banyak diteliti oleh peneliti sebelumnya diantaranya adalah : ( A.H Garjito et al., 2014; Ady \& Wijono, 2013; Hartoyo \& Setiaji, 2018; Jaenudin \& Frida, 2015; Kiki Setiawan, 2015; Rafiansyah \& Puteri, 2019)

\section{METODE PENELITIAN}

Desain penelitian yang dilakukan adalah desain penelitian konklusif dimana terdapat hipotesis yang akan diverifikasi melalui penelitian. Sehingga penelitian ini merupakan penelitian kuantitatif. Analisis statistik deskriptif digunakan dalam penelitian ini untuk memberikan gambaran atau deskripsi mengenai variabel-variabel peneliatian yaitu: gaya kepemimpinan, kepuasan kerja, motivasi kerja, dan kinerja Account Representative (AR).

Penelitian ini dibatasi pada populasi Account Representative pada Kantor Pelayanan Pajak (KPP) Pratama di Lingkungan Kantor Wilayah DJP Sumatera Utara II. Metode pengambilan sampel yang digunakan pada penelitian ini adalah non random sampling, artinya peneliti tidak memberikan kesempatan yang sama pada anggota populasi untuk dijadikan anggota sampel. Teknik yang digunakan dalam penentuan sampel adalah Purposive Sampling atau Judgment Sampling, yakni teknik yang dilakukan berdasarkan kriteria yang disesuaikan dengan tujuan penelitian atau pertimbangan dari peneliti. Adapun Account Representative yang dijadikan sampel adalah Account Representative yang bertugas di bagian pengawasan Wajib Pajak yaitu yang ditempatkan di Seksi Pengawasan dan Konsultasi II, III dan IV pada KPP Pratama.

\section{HASIL DAN PEMBAHASAN}

Artikel ini menganalis dan membahas tentang variabel-variabel Manajemen Sumber Daya Manusia (MSDM) yaitu: Gaya Kepemimpinan , Kepuasan Kerja, Motivasi Kerja dan Kinerja Karyawan. Study-study terdahulu yang dianggap relevan dengan tulisan ini yaitu :

1. Gaya Kepemimpinan memiliki hubungan dan Berpengaruh terhadap Kinerja Karyawan 
Gaya pemimpin merupakan salah satu faktor penting yang dapat mempengaruhi kinerja pegawai. Menurut Astria et al., (2015) gaya kepemimpinan yang tepat sangatlah penting dalam meningkatkan kinerja karyawan. Pemimpin juga perlu berpartisipasi dalam komunikasi kepada karyawan, agar pemimpin dapat mengetahui apa keluhan dan keinginan karyawan dalam melakukan pekerjaan. Hal ini semata-mata dilakukan oleh seorang pemimpin untuk dapat meningkatkan kinerja karyawan dan mencapai tujuan dari organisasi.

Penelitian Rahadian \& Suwandana, (2017) bahwa Gaya kepemimpinan dapat memengaruhi peningkatan kepuasan kerja kearah yang lebih tinggi. Penyebab positif dan signifikannya pengaruh gaya kepemimpinan terhadap kepuasan kerja diakibatkan karena pimpinan selalu memberikan kesempatan kepada karyawan untuk bertanya tentang permasalahan kerja yang memang dianggap benar-benar penting sehingga berdampak pada tingginya kepuasan kerja karyawan dalam menyelesaikan pekerjaan Stress kerja yang rendah tidak mampu memengaruhi peningkatan kepuasan kerja. Kondisi tersebut diakibatkan karena karyawan sangat cemas dalam menghadapi berbagai tuntutan tugas yang memicu kinerjanya dan perusahaan senantiasa memberhentikan karyawannya yang tidak dapat menghadapi tuntutan tugasnya Gaya kepemimpinan dominan berpengaruh terhadap kepuasan kerja. Kondisi tersebut disebabkan karena pimpinan selalu memberikan kesempatan kepada karyawan untuk bertanya tentang permasalahan kerja yang memang dianggap benar-benar penting sehingga berdampak pada tingginya kepuasan kerja karyawan.

\section{Kepuasan Kerja memiliki hubungan dan Berpengaruh terhadap Kinerja Karyawan}

Setiap organisasi selalu berusaha untuk mencapai tujuannya, sehingga, mereka harus berkonsentrasi pada beberapa aspek. Salah satunya adalah sumber daya manusia (SDM) organisasi yang dipandang sebagai sumber penting. Organisasi diharapkan untuk selalu menjaga tenaga kerja yang terlatih dengan baik dan efektif (Nimalathasan, 2012). Menjaga kinerja karyawan merupakan salah satu cara untuk dapat memenuhi tujuan organisasi.

Menurut Davis dan Newstron (1989) dikutip dari Rahmawati dan Widagdo (2001) kepuasan kerja adalah seperangkat perasaan pegawai tentang menyenangkan atau tidak pekerjaan mereka, serta seperangkat keinginan, kebutuhan, hasrat dan pengalaman masa lalu yang menyatu membentuk harapan kerja. Variabel ini diukur dengan skala likert 5 poin mulai dari sangat tidak setu (1), tidak setuju (2), kurang setuju (3), setuju (4), sampai sangat setuju (5).

Kepuasan kerja adalah perasaan senang maupun tidak senang terhadap pekerjaannya. Perasaan senang ataupun tidak senang tersebut muncul karena pada saat karyawan bekerja mereka membawa serta keinginan, kebutuhan, dan pengalaman masa lalu yang membentuk harapan kerja mereka. Harapan kerja inilah yang merupakan motivasi kerja karyawan. Makin tinggi harapan kerja ini dapat terpenuhi, maka makin tinggi tingat kepuasan kerja karyawan.

Kepuasan kerja merupakan salah satu faktor penting dalam meningkatan kinerja karyawan. Karyawan termotivasi untuk bekerja dengan baik, tetapi tidak merasa puas dengan kerja mereka. Beberapa alasan yang memungkinkan adalah karyawan membutuhkan pekerjaan dan uang. Uang dan pekerjaan tergantung pada kinerja yang baik, di satu sisi karyawan merasa bahwa mereka berhak mendapatkan gaji yang lebih atas kinerja yang diberikan kepada perusahaan, namun tidak mendapatkannya

Penelitian Ayu Desi Indrawati (2017) dapat disimpulkan bahwa kepuasan kerja memiliki arti penting bagi karyawan maupun perusahaan, khususnya demi terciptanya keadaan positif di lingkungan kerja. Robbins (2006) juga menyatakan menganai dampak kepuasan kerja pada kinerja karyawan. Karyawan yang merasa puas akan pekerjaannya memiliki 
kemungkinan yang lebih besar untuk membicarakan hal-hal positif tentang organisasinya, membantu yang lain, dan berbuat kinerja pekerjaan mereka melampaui perkiraan normal.

\section{Motivasi Kerja memiliki hubungan dan Berpengaruh terhadap Kinerja Karyawan}

Wexley dan Yukl dalam Soetrisno, (2010:110) memberikan batasan mengenai motivasi sebagai sesuatu yang menimbulkan semangat kerja. Motivasi adalah mempersembahkan daya penggerak yang menciptakan kegairahan kerja seseorang, Agar mereka mau bekerja secara efektif dan terintegrasi dengan segala daya upayanya untuk kepuasan kepuasan. Beberapa pendapat tersebut di atas, mewakili pengertian dari perspektif internal dimana motivasi dipandang bersumber dari dalam diri seseorang, maupun dari perspektif eksternal, yang dipandang bersumber dari luar diri seseorang. Kedua jenis motivasi tersebut dapat mempengaruhi kehidupan perilaku Manusia dan perilaku individu itu hakekatnya adalah berorientasi pada tujuan.

Motivasi yang tinggi yang ada pada diri karyawan merupakan modal bagi suatu perusahaan untuk dapat mewujudkan kepuasan kerja yang tinggi pula, hal ini tentunya merupakan harapan yang ingin dicapai oleh perusahaan. Perusahaan dapat memilih cara memotivasi karyawan dengan tepat dan sesuai dengan situasi dan kondisi perusahaan.

Hasil penelitian Olivia Theodora (2015) menunjukkan bahwa motivasi yang terdiri dari motivasi existance, relatedness, dan growth berpengaruh secara signifikan (hubungan yang simultan) terhadap kinerja karyawan dengan penelitian pada PT. SMG di Surabaya. Penelitian lain irawati et, al. ( 2019) menunjukan bahwa variabel motivasi berhugungan dengan kinerja karyawan, dan didukung penelitian lainnya yaitu. I Wayan Arya Lantara (2018), Hermawati \& Suganjar, (2020),Edwy, (2016), dan Hidayat, (2019) yang menunjukkan motivasi kerja berpengaruh positif dan signifikan terhadap kinerja karyawan.

\section{Conceptual Framework}

Berdasarkan Kajian teori dan hubungan antar variabel maka model atau Conceptual Framework artikel ini dalam rangka membangun hipotesis adalah sebagai berikut:

1. Pengaruh Gaya Kepemimpinan terhadap kinerja karyawan (Account Representative) berdasarkan hasil riset : (Astria Khairiziah, et al.,2015; Pinatih \& Gorda, 2017; Rahadian \& Suwandana, 2017; Riyanto, Pratomo, et al., 2017).

2. Pengaruh Kepuasan Kerja terhadap kinerja karyawan (Account Representative) berdasarkan hasil riset : ( Prayatna \& Subudi, 2016; Rahadian \& Suwandana, 2017; Rismayadi \& Maemunah, 2016)

3. Pengaruh Motivasi Kerja terhadap kinerja karyawan (Account Representative) berdasarkan hasil riset : ( D.I Ayu, 2013; A.H Garjito et al., 2014; Ady \& Wijono, 2013; Kiki Setiawan, 2015; Theodora Olivia,2015)

Berdasarkan hasil study literatur terdahulu serta hasil penelusuran pemikiran dan pendapat para ahli, maka dapat dikembangkan kerangka pemikiran artikel ini seperti dibawah ini : 


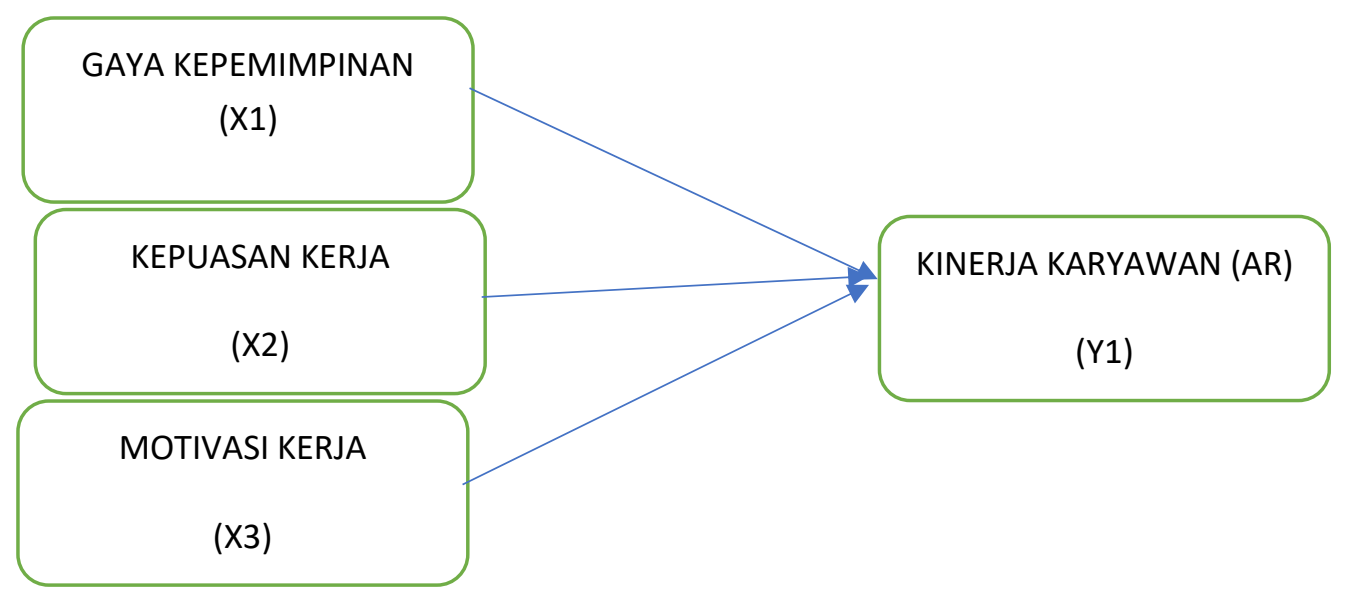

Gambar : Conceptual Frame Work

Berdasarkan Kajian teori dan review hasil riset dari jurnal yang relevan serta gambar dari conceptual framework, maka Gaya Kepemimpinan, Kepuasan Kerja dan Motivasi Kerja memiliki pengaruh terhadap kinerja karyawan (Account Representative) pada Kanwil DJP Sumut II baik secara langsung maupun tidak langsung.

\section{KESIMPULAN DAN SARAN Kesimpulan}

Berdasarkan rumusan artikel, hasil dan pembahasan yang di kaji dan di bahas pada artikel ini, maka dapat disimpulkan rumusan untuk membangun suatu hipoteis guna untuk riset selanjutnya sebagai berikut :

1. Gaya Kepemimpinan memiliki hubungan dan pengaruh pada kinerja pegawai (Account Representative) pada Kanwil DJP Sumut II

2. Kepuasan Kerja memiliki hubungan dan pengaruh pada kinerja pegawai (Account Representative) pada Kanwil DJP Sumut II

3. Motivasi Kerja hubungan dan pengaruh pada kinerja pegawai (Account Representative) pada Kanwil DJP Sumut II

\section{Saran}

Bersdasarkan hasil pembahasan sebelumnya dan Kesimpulan di atas, penulis menyadari bahwa masih banyak faktor lain yang mempengaruhi Kinerja Pegawai Account Representative di Kanwil DJP Sumut II, oleh karena itu masih di perlukan kajian yang lebih lanjut lagi untuk melengkapi faktor-faktor lain yang dapat memepengaruhi kinerja Account Representative atau pegawai pada umumnya.

\section{DAFTAR RUJUKAN}

Ady, F \& Wijono, D. (2013). Pengaruh Motivasi Kerja Terhadap Kinerja Karyawan. Jurnal Maksipreneur, 2(2) Hal. 101-112

Amilin, Rosita Dewi. 2008. Pengaruh Komitmen Organisasi Terhadap Kepuasan Kerja Akuntan Publik Dengan Role Stress sebagai Variabel Moderating. JAAI Vol.12. No.1, Juni 2008:13-24.

Amrozi. (2017). Pengaruh Kemepimpinan,Kepuasan Kerja dan Komitmen Organisasi Terhadap Kinerja Karyawan Di RUmah Sakit Besuki-Situbondo. Digital Repository Universitas Jember, 9-35. http://repository.unimus.ac.id/411/

Aritonang, Lerbin R. 2016. Metode Penelitian Bisnis. Tangerang Selatan: Universitas Terbuka. 
Biatna Dulbert. 2008. Analisis Faktor Gaya Kepemimpinan dan Faktor Etos Kerja terhadap Kinerja Pegawai pada Organisasi yang telah Menerapkan SNI 19-9001-2001.

Edwy, F. M. (2016). Pengaruh Komitmen Organisasional, Komitmen Profesional, Motivasi Kerja, Konflik Peran, Ketidakjelasan Peran Dan Kelebihan Peran Terhadap Kepuasan Kerja Auditor Pada Kantor Akuntan Publik Di Pekanbaru, Padang Dan Batam Oleh: JOM FEKON, 3(1).

Gardjito, Mussadieq., dan Gunawan Eko Nurtjahjono. 2014. Pengaruh Motivasi Kerja, dan Lingkungan Kerja terhadap Kinerja Karyawan (Studi pada Karyawan Bagian Produksi PT. Karmand Mitra Andalan Surabaya). Jurnal Administrasi Bisnis (JAB) 13, hal: 1-8.

Gita, Robertus., dan Ahyar Yuniawan. 2016. Pengaruh Gaya Kepemimpinan Transformasional, Motivasi Kerja, dan Budaya Organisasi terhadap Kinerja Karyawan (Studi pada PT. BPR Arta Utama Pekalongan). Jurnal Studi Manajemen dan Organisasi 13, hal: 161-170.

Hafizurrachman HM. (DR, dr, MPH), "Pengaruh Gaya Kepemimpinan Atasan, Lingkungan Kerja, Dan Motivasi Kerja Terhadap Kinerja Kepala Program Studi Kesehatan dan Kedokteran Pada Perguruan Tinggi Swasta Wilayah Kopertis III (Disertasi)”. Jakarta, UNJ, 2007.

Hermawati, R., \& Suganjar. (2020). Analisis Pengaruh Motivasi, Kompensasi, dan Pengembangan SDM Terhadap Kinerja Anak Buah Kapal Deck Departement Melalui Variabel Intervening Kepuasan Kerja. Majalah Ilmiah Bahari Jogja, 18(1), 1-13

Hidayat, A. (2019). Pengaruh Budaya Organisasi Dan Motivasi Kerja Terhadapa Kinerja Karyawan Melalui Kepuasan Kerja. Jurnal Ilmiah Ekbank, 2(juni), 17-27.

Indrawati, Ayu Desi. 2013. Pengaruh Kepuasan Kerja terhadap Kinerja Karyawan dan Kepuasan Pelanggan Pada Rumah Sakit Swasta di Kota Denpasar. Jurnal Manajemen, Strategi Bisnis, Dan Kewirausahaan . Vol.7 No.2, hal: 135-142.

I Wayan Arya Lantara. (2018). Pengaruh Motivasi Kerja Terhadap Kinerja Karyawan Dengan Kepuasan Kerja Sebagai Variabel Intervening Di Pt. Indonesia Tourism Development Corporation (Itdc). Jurnal Pendidikan Ekonomi Undiksha, 10(1), 231-240.

Kartono, Kartini, 2008 : Pemimpin dan Kepemimpinan. Jakarta : PT. Raja Grafindo Persada. Khairizah, A., Noor, I., \& Suprapto, A. (2017). Pengaruh Gaya Kepemimpinan Terhadap Kinerja Karyawan . Journal Administrasi Publik, 3 (7), 1268-1272.

Komposisi Pegawai Kementerian Keuangan. http://www.sdm.kemenkeu.go.id/. Diakses pada tanggal 25 Oktober 2020 pukul 21:00 WIB.

Kusumawardhani, Eny., Wahyudi, Amin., dan Sutarno. 2018. Pengaruh Kepemimpinan, Motivasi dan Profesionalisme terhadap Kinerja Karyawan PT Industri Kereta Api Indonesia (Persero) di Madiun. Jurnal Manajemen Sumber Daya Manusia. Vol. 12. No. 1. hal: 45-60.

Nawawi, Hadari. 2012. Metode Penelitian Bidang Sosial. Yogyakarta: Gajah Mada University Press.

Prayatna, A., \& Subudi, I. (2016). Pengaruh Gaya Kepemimpinan Terhadap Stres Kerja Dan Kepuasan Kerja Karyawan Pada Fave Hotel Seminyak. E-Jurnal Manajemen Universitas Udayana, 5(2), 252587.

Rahadian, M., \& Suwandana, I. (2017). Pengaruh Gaya Kepemimpinan Dan Iklim Organisasi Terhadap Kepuasan Kerja Karyawan. E-Jurnal Manajemen Universitas Udayana, 6(6),

Rismayadi, B., \& Maemunah, M. (2016). Pengaruh Motivasi Kerja, Kepemimpinan dan Budaya Organisasi Terhadap Kepuasan Kerja Karyawan serta Dampaknya pada Kinerja Perusahaan (Studi kasus pada PT. Concord Indonesia). Jurnal Manajemen \& Bisnis Kreatif, 2(1).251085. 
Rivai, Veithzal. 2011, Manajemen Sumber Daya Manusia untuk Perusahaan: dari Teori ke Praktik, Jakarta : Raja Grafindo Persada.

Riyadi, S. (2011). Pengaruh Kompensasi Finansial, Gaya Kepemimpinan, dan Motivasi Kerja Terhadap Kinerja Karyawan Pada Perusahaan Manufaktur di Jawa Timur. Jurnal Manajemen dan Kewirausahaan . Vol 13 No.1 Hal :40-45

Riyanto, S., Pratomo, A., \& Ali, H. (2017). Effect Of Compensation And Job Insecurity On Employee Engagement (Study On Employee Of Business Competition Supervisory Commission Secretariat). International Journal of Advanced Research. https://doi.org/10.21474/ijar01/4139

Setiawan, Kiki Cahaya (2015). Pengaruh Motivasi Kerja Terhadap Kinerja Karyawan Level Pelaksana di Divisi Operasi PT. Pusri Palembang,PSikis-Jurnal Psikologi Islami vol.12 no,2. Hal: 45-53

Sirulingga,"Pengaruh Motivasi, Kemampuan dan Kepemimpinan Terhadap Kinerja Pegawai", Jakarta: Universitas Esa Unggul, 2004.

Soetrisno, E. (2010). Manajemen Sumber Daya Manusia. Jakarta : Kencana.

Sulistyawati, Nanik., Fasochah., dan Darsono. 2016. Pengaruh Profesionalisme dan Motivasi Kerja terhadap Kinerja Guru dengan Lingkungan Kerja sebagai Variabel Moderasi (Studi pada SMP Negeri se Kecamatan Boja Kabupaten Kendal). Jurnal Dharma Ekonomi. No.43 / Th.XXIII/ April 2016. ISSN : 0853-5205.

Theodora, Olivia. 2015. Pengaruh Motivasi Kerja terhadap Kinerja Karyawan PT Sejahtera Motor Gemilang. AGORA. Vol.3 No.2 hal:187-195

Trisnaningsih, Sri. 2007. Independensi Auditor Dan Komitmen Organisasi Sebagai Mediasi Pengaruh Pemahaman Good Governance, Gaya Kepemimpinan Dan Budaya Organisasi Terhadap Kinerja Auditor. Unhas Makassar, 26-28 Juli 2007. Universitas Pembangunan Nasional "Veteran", Jawa Timur.

Wahyudi, Amin., dan Jarot Suryono. 2006. Analisis Pengaruh Gaya Kepemimpinan, Motivasi dan Lingkungan Kerja terhadap Kinerja Pegawai. Jurnal Manajemen Sumber Daya Manusia. Vol. 1, No. 1. hal: 1-14. 